\title{
GENDER, EMOTION AND TRANSCENDENCE IN JOHN KEATS' “ODE ON MELANCHOLY” AND FELICIA DOROTHEA HEMANS' "ODE TO CHEERFULNESS"
}

by

Dana Mitchell

BAH, Queen's University, 2019

\author{
A Major Research Paper \\ Presented to Ryerson University \\ in partial fulfillment of the requirements for the degree of \\ Master of Arts in the English MA Program \\ in Literatures of Modernity
}

Toronto, Ontario, Canada, 2020

(C) Dana Mitchell, 2020 


\section{AUTHOR'S DECLARATION FOR ELECTRONIC SUBMISSION OF A MAJOR RESEARCH PAPER}

I hereby declare that I am the sole author of this MRP. This is a true copy of the MRP, including any required final revisions.

I authorize Ryerson University to lend this MRP to other institutions or individuals for the purpose of scholarly research. I further authorize Ryerson University to reproduce this MRP by photocopying or by other means, in total or in part, at the request of other institutions or individuals for the purpose of scholarly research.

I understand that my MRP may be made electronically available to the public. 


\section{Introduction}

Melancholy has been tied to the Romantic literary tradition and its preoccupation with intensely emotional experiences, as well as the poetic forms that best accommodate them. Odes, elegies and laments are remarkably prominent in the Romantic canon and have come to epitomize the nineteenth century as a time "steeped in melancholy" (Bowring 38). While Romanticism is largely remembered as an age of melancholy, there were many women poets who were unable to fully access these expressions of sorrow, therefore relying on more joyful emotions that are not as closely associated with the period. Poets such as Felicia Hemans and Letitia Elizabeth Landon wrote on topics of mild sentiment and the domestic, working within structures of feminine identity that were both acceptable and commercial. Although these writers often fought against such conventions in their work, the masculine gendering of melancholy and its connection to poetic genius and transcendence ultimately reduces the ability of women writers to achieve an eternal reputation in the canon of Romantic literature.

This paper compares John Keats' “Ode on Melancholy” and Felicia Dorothea Hemans' "Ode to Cheerfulness" to uncover intersections between gender, emotion, and transcendence working within the Romantic period. Hemans rejects the melancholic conventions that were upheld by poets like Keats, seeking transcendence through other, more accessible emotions. By situating these poems in conversation with one another, I explore the ways that Keats and Hemans represent gendered experiences of being in the world - and how this relates to their own roles as Romantic poets and their intended readership. Prior scholarship in this field is diverse and far-reaching, however there is a distinct lack of research around emotions of joy and cheerfulness. I will build upon this knowledge by highlighting these emotions and analyzing their gendered associations, particularly as they relate to concepts of transcendence - of both the 
self and the everyday, as well as the canonized transcendence of a poet's body of work. By addressing the varying power dynamics between men and women, joy and melancholy, and transcendent and earthly experiences, this paper questions the gendered conventions embedded in Romanticism - including the transience of feminine beauty and the role of women in service to men - to establish less dichotomized conceptions of women as writers, readers, and subjects.

\section{John Keats}

Romantic writers often explored extremes of emotion, with a notable emphasis on melancholy. The melancholic spirit of the Romantic period permeates the work of great Romantic poets - including John Keats - who are recognized for the ways their writing engages with states of sorrow, reflecting the unease of changing social norms within the eighteenth and early nineteenth centuries. While melancholy can be understood as a sad and pensive emotional state, it was also linked to notions of creativity and poetic mastery within the Romantic period (“Melancholy"). As Jacky Bowring points out, “[t]he Romantic poets and painters were characterised by moods and demeanours that were described as melancholy or depressive, conditions which were considered generators of artistic impulse" (Bowring 38). Robert Burton's The Anatomy of Melancholy provided a definitive account of the nature of melancholy and its various causes, symptoms, and potential cures. He illustrates the nature of melancholy as both a disposition and a habit, describing it as "the character of mortality" (Burton 925) and stating that no man is free of sorrow, that life is "a succession of pleasure and pain" (931). However, despite this broad definition, melancholy was not a universally available sentiment. Elizabeth A. Dolan argues that women in the nineteenth century had to navigate between the medical and cultural limitations of melancholia, which often discredited their emotions and labelled them as hysterical 
and irrational (Dolan 238). Poets such as Charlotte Smith were forced to negotiate these emotional barriers in order to produce art that was taken seriously while also working within the social limitations of their gender (238). In this sense, the connection between melancholy and the male poet works to elevate the masculine perspective, dismissing the feminine voice as sentimental and unworthy of the same poetic transcendence.

As one of the central voices of the Romantic period, John Keats embodies the ideal of the male Romantic poet. While Keats opposed the Wordsworthian mode of poetic creation - what he termed the "egotistical sublime" - his quest for literary greatness still imbues his poetry with a strong sense of self. Keats stepped away from his occupation as a physician to pursue a life of poetry, driven by a desire to achieve poetic immortality and a conviction that it was possible. In a letter to George and Georgina Keats in 1818, he writes, "I think I shall be among the English Poets after my death" (Krsmanovic). This prophetic statement shows Keats' wish to achieve greatness specifically after his death, suggesting that one of the main goals of his writing was canonization.

The Romantic period saw a growing preoccupation with the afterlives of a writer's body of work, a transition that was fuelled by developments in printing, the commercialization of poetry, and the spread of literacy (Bennett 38). This focus on posterity was also evident in Keats' own self-construction. Andrew Bennett argues that "[c]rucial to the figuration of Keats as Poet is an early death which is presciently inscribed within the poet's life and work - an early death which he knows about" (143). Working within the tradition of the "young genius", which was established by writers such as Thomas Chatterton, Keats focused much of his work on the decaying body and the acclaim that would follow his death (144). This is seen especially in poems such as "Ode on a Grecian Urn" and "Ode to a Nightingale", in which images of the 
poet's failing body open up possibilities for immortality and a successful afterlife (151). In this way, Keats aligned himself with the reputation of writers who had come before him and predetermined the fate of his own work through themes and symbols in his poetry. By emphasizing the posterity of his writing, Keats paved the way for his own canonization achieving a sort of poetic transcendence.

Another method of transcendence that informed Keats' writing was his conception of the "camelion poet", a term he used to describe the unbounded way that poets assume different perspectives in their writing without passing judgement. He writes: "A Poet is the most unpoetical of any thing in existence; because he has no Identity - he is continually in for - and filling some other Body - The Sun, the Moon, the Sea and Men and Women who are creatures of impulse are poetical and have about them an unchangeable attribute - the poet has none; no identity - he is certainly the most unpoetical of all God's Creatures" ("Letter \#99: To Richard Woodhouse, 27 October 1818”). While Margaret Homans argues that Keats' poetic views align him with a certain feminine passivity, it is also his privilege as a man that allows him to occupy multiple bodies and identities. Unlike his female contemporaries who would not have been able to separate their poetry from their gender, Keats can appropriate multiple perspectives without compromising his station in society or the merit of his work. In this way, it is Keats' male identity that grants him access to the realm of transcendent experience and poetic greatness.

In Keats' "Ode on Melancholy", melancholy is represented as a desirable and ultimately masculine experience, the speaker describing the "sovran shrine" seen by "none save him whose strenuous tongue/ Can burst Joy’s grape against his palate fine" (lines 27-28). The use of the man's "strenuous tongue" and his "palate fine" suggest a certain level of skill and strength needed to achieve a place among Melancholy's prized possessions. By experiencing the "sadness 
of her might" (29), the man earns his place "among her cloudy trophies hung" (30), relieving himself of the burdens of an earthly existence and achieving a state of sublimity. The realization that pain and pleasure are irrevocably linked is one that can only be achieved through a male perspective. The repetition of masculine pronouns in the final four lines of the poem solidifies this authoritative stance and enacts a form of male dominance against the feminized force of Melancholy.

Melancholy is personified as a woman, but even with the power to deceive and entrap men, she is still overcome by the force of male agency. The sexual imagery of the man entering Melancholy's shrine and tasting the "sadness of her might" places their interaction within a heteronormative structure of power. The strength and skill exerted by the man to reach Melancholy, despite being claimed as her victim at the end of the poem, shows the ultimate desirability of attaining a place among her trophies. The agency suggested in this act of sacrifice reverses the power dynamics within the scene, demonstrating that it is not the sole male figure, but Melancholy herself who is being overcome in pursuit of sublime experience.

The use of the female form - both physically and imaginatively - to attain male transcendence, is a theme that is present throughout Keats' ode. In the first stanza, the speaker alludes to the female goddesses Proserpine and Psyche. Proserpine, the goddess of wine, and Psyche, the goddess of the soul, are both used to evoke a melancholic state and situate the poem within a larger literary tradition. The Romantics were highly influenced by antiquity, often using characters from Greek and Roman mythology to establish their own vision of modernity. These ancient figures also harken back to great literary masters such as Dante and Virgil, giving the Romantic poets authorial weight and helping to secure their place as canonical writers. The use of goddesses to describe a masculine experience of melancholy and to elevate the work of a male 
poet demonstrates the intricate ways that female forms are used to shape ideal representations of masculinity. The feminine form is also introduced in a more physical way in the ode through the presence of a "mistress". The speaker tells the melancholic figure to "[e]mprison her soft hand" (19) and "feed deep, deep upon her peerless eyes" (20), taking possession of her body to overcome his melancholic state. The fact that she is also presented as "thy mistress" further positions her as subservient to her male companion.

Although the dominant figure in the poem - to whom it is addressed - is never explicitly gendered, the eroticized encounter with the mistress suggests a masculine identity. The initial gendering of the female figure before her male counterpart demonstrates her subordinate position - her identity is bound to her sexual discernibility and her connection to nature, limiting her depth of character and grounding her within an earthly sphere. The speaker advises the man to "glut thy sorrow on a morning rose" (15) or "on the wealth of globed peonies" (17). Similarly, he is told to overpower his melancholy through the body of his mistress. By aligning women and nature as beautiful objects to be used and discarded for the purpose of male creation, the threat they pose against masculine selfhood - as uncontrollable Others - is eradicated.

Women were typically associated with nature in the Romantic tradition. As Aidan Day points out with regards to Book XIII of Wordsworth's The Prelude: "The sublime moment is peculiarly male. Nature and the feminine can help facilitate this moment of sublime apprehension, but that is as far as it goes. Priority and ultimacy reside with the masculine while the feminine is accorded a secondary, supportive role" (Day 163). Nature and the feminine are aligned in a similar way in Keats' ode, as secondary players to a masculine experience of the sublime. While this alignment promotes male dominance, it also anchors women within a material plane, making it difficult to separate them from their physical bodies and attain a 
transcendent state. Instead, their identities are assumed and manipulated by men in order to achieve their own transcendence. Anne K. Mellor describes this capacity for appropriation in her book Romanticism and Gender: "By taking on the feminine virtues of compassion, mercy, gentleness and sympathy, the male Romantic poet could claim to speak with ultimate moral as well as intellectual authority" (Mellor 23-24). The use of a woman in Keats' ode to both define and aid in a man's quest for sublimity depicts the larger inferiority of her gender - the mistress serving as a means for masculine self-realization and transcendence, even though she is unable to attain these things for herself.

The concept of possession in "Ode on Melancholy" is intrinsically linked to male authorial power. The fact that the mistress' hands are depicted as "soft" demonstrates a certain lack of worldly experience - the emphasis on their delicacy working to eliminate the threat of another poetic voice and place the mistress in a subservient position to both the man and the speaker. Her eyes are also described as "peerless", however despite their incomparable nature or perhaps because of it - they are reduced to mere objects of consumption in the pursuit of male transcendence. As parts of the body typically associated with creative vision and execution, the use of the mistress' eyes and hands as a means of attaining larger male aspirations shows a disconnect between women and poetic expression. Their bodies are not used to create for themselves, but as tools for masculine creation. In addition, it is a woman's very embodiment the focalization of her body as an indivisible marker of worth - that ultimately grounds her, excluding women from a greater tradition of canonized male poetry.

Margaret Homans examines Keats' ambivalent relationship to women readers in the article "Keats Reading Women, Women Reading Keats". She describes how Keats struggled with his own sense of masculinity, which complicated his relationship with women and a 
growing female readership (Homans 347). After Keats' publisher Richard Wodehouse suggested that The Eve of St. Agnes would be unfit for a female readership, Keats responded that "he does not want ladies to read his poetry: that he writes for men" (Banerjee 42). Despite wanting to write primarily for men, the growing number of women readers at the beginning of the nineteenth century meant that Keats was forced to contend with the threat of a female audience. He even recognized that his poor book sales were partly a result of "the offence that ladies take to [him]" and that he has "a tendency to class women in [his] books with roses and sweetmeats, they never see themselves dominant" (Homans 346). Poems like "Ode on a Grecian Urn" illustrate this gendered tension in its description of two lovers frozen in time. The speaker declares: "Forever wilt thou love, and she be fair!" (Keats, "Ode on a Grecian Urn", line 20). This line gives power to the male figure in his ability to forever feel love, whereas the woman is praised for her everlasting beauty, relegating women to the realm of passive beauty.

In addition to the subordination of women, Homans describes how Keats attempts to eradicate the threat of the female Other within his writing through objectification: "A female figure promises a dissolution of the poet's identity that is at once pleasurable and profoundly threatening, so that he defends himself by substituting his words for her and by objectifying her" (Homans 355). The objectification of women by men limits their potential as readers and writers. By being associated with 'thingness', women cannot be viewed as thinking beings capable of judgment or creating great works of art. The gendering of melancholy is yet another factor that affects authorial power within the Romantic period. As Susan T. Wolfson describes, melancholy was viewed as a symbol of perceptual depth among male poets and as a marker of feminine sensibility among female poets (Wolfson 443). This treatment of melancholy reveals a structure of power around poetic creation that stifles the voices of women writers. For male poets - 
including Keats - melancholy acts as a tool to help them move closer to poetic greatness, however for their female counterparts it acts to further ground them within a restrictive domestic sphere.

In the opening line of the final stanza of the "Ode on Melancholy", the speaker declares: "She dwells with Beauty - Beauty that must die" (Keats 21). The finality of this statement reflects women's incapacity for transcendence, as they are relegated to an earthly sphere in which one's value dies along with beauty. The melancholic sentiment behind this idea stems from the fact that a woman's identity - and by extension her worth - is derived from impermanent aesthetic qualities. In Keats' ode, the value of these qualities is based on their very transience, allowing the male figure to realize the sublimity of life as a mixture of both pleasure and pain. By attaining a place among Melancholy's trophies, he is able to achieve a transcendent state that is not bound by the earthly sphere or its impermanent faculties of pleasure and beauty. Excluding women from these experiences and consigning them to supporting roles limits their capacity to be understood beyond their relationships to men, nature, and their own bodies. While women dwell and deteriorate in the realm of transient Beauty, men are given the opportunity to live eternally as sublime beings, poets and keepers of truth.

Edmund Burke defines the sublime in contrast to the beautiful, as analogous to the opposition between strength and weakness, immensity and smallness (Day 159). If the sublime is associated with male characteristics, then the attainment of sublime experience is therefore inherently male. Burke writes in A Philosophical Enquiry into the Origin of our Ideals of the Sublime and Beautiful that "[ $[\mathrm{t}] \mathrm{here}$ is a wide difference between admiration and love. The sublime, which is the cause of the former, always dwells on great objects, and terrible; the latter on small ones, and pleasing; we submit to what we admire, but we love what submits to us" 
(Burke 192). The inherent gendering of Burke's comparison between love and admiration dichotomizes male and female experience, placing women within an oppressive structure of power. As Mellor notes, "[t]he ideal woman, then, is one who engages in a practice of what today we would call female masochism, willingly obeying the dictates of her sublime master" (Mellor 108). Placing women within a subordinate position excludes them from sublime experiences. By framing them as "small" and "weak", Burke not only limits their capacity to achieve higher states of being but asserts that it is in their very nature to passively accept their supporting role within the ultimate pursuit of male sublimity. Burke also describes his ability to find the sublime in facets of the earth that evoke a sense of infinity (Burke 148). In this way, the earth is presented as something that can be used in order to achieve a connection with infinity. As previously discussed, women and nature become aligned as a way to support male authority and are both used as impermanent resources to help men achieve transcendence. In this case, women and nature are not only being used to achieve sublime experiences, but to define them and solidify them as wholly masculine.

The existence of Keats' ode itself works to solidify male dominance in the realm of poetic creation. When the mistress is physically consumed and Melancholy has attained her trophy, it is the male figure that remains immortal. Similarly, once the poem comes to a close, it is the male poetic voice that remains in the form of the third-person speaker and within Keats' larger poetic legacy. Considering the transience of women and nature as they are situated in the poem, the male poet's station is elevated by comparison, exerting his mastery both artistically and socially. As an ode "on" melancholy, the title also suggests an authoritative or dominant stance on the subject, the feminized Melancholy taking on a subservient role once again, this time by the poet rather than her male conqueror. 
Melancholy is one of many ways that the social and artistic constructions of the nineteenth century worked to elevate male poets and restrict female voices. The grounding of the female form through objectification and domestic ideals limits their access to emotions such as melancholy, which can be used in the pursuit of sublime experience and the attainment of poetic transcendence. By excluding women from certain experiences and emotions - including melancholy - their ability to achieve the same poetic esteem as their male contemporaries is limited and their writing consigned to the realms of sentimentalism and the domestic affections. Without this freedom of expression, the legacy of women's work, as it relates to canonization, was not guaranteed to the same extent that it was for poets like Keats. I will explore these topics in more detail in the following section as I examine Felicia Dorothea Hemans' "Ode to Cheerfulness" and the subversive ways that female writers in the Romantic period challenged their roles as both women and poets.

\section{Felicia Dorothea Hemans}

"Ode to Cheerfulness" is the first poem in Felicia Dorothea Hemans' 1812 anthology The Domestic Affections, and Other Poems. The collection, which was aimed at a female readership, covers topics of sentiment and family life, epitomizing Hemans' career as a domestic "poetess". Poems such as "To my Mother" and "Song. The Smile" focus on a woman's duty to serve others and control her emotions in both familial and romantic relationships. Hemans writes of "goodhumour's mild control" ("Song. The Smile", line 9) and the "softer light" of filial love ("To my Mother", line 33), presenting women as passive beings that are defined by their relationships and their ability to properly navigate the domestic sphere. However, as much as Hemans was regarded as an ideal feminine figure and poet, Susan J. Wolfson points out that her poetry also 
"present[s] a diverse, often divided array of female characters and social perspectives" (Wolfson 140). In this way, Hemans not only represents a feminine ideal, but many facets of a woman's identity including strength, desire, and even transcendence. "The Bards, To the Soldiers of Caractacus", another poem from The Domestic Affections, contradicts the mild messaging in some of Hemans' other works. The poem relays the battle cries of a British army fighting for freedom against the Roman conquest. Hemans writes: "What steel can bind,/ The soaring mind,/ Free as the light, the wave, the wind?" ("The Bards", lines 65-67). While gender is never mentioned explicitly, this passage suggests that anyone can achieve transcendence or freedom since the mind can never be truly captured. This diverse expression of female identity does not discredit the domestic norms that were prevalent in the nineteenth century but presents them as only one mode of representing women and their larger position within society.

During the Romantic period, the affections - such as joy and wonder - were often associated with female identity and domesticity (Reno 8). Following William Godwin's conception of the term, the affections can be understood as more than just feelings, but as "sources and theories of knowledge" (8). In the works of women writers, such mobility between sentiment and knowledge opens up a very useful middle ground. Seth Reno argues that "[i]n Hemans' poetry, the affections emerge as a dialectical concept between the sublime transcendence of love and the earthly, bodily experience of affect" (5). The ability to achieve forms of transcendence while also embodying the earthly conventions of one's gender, enables Hemans to both support and challenge her roles as a woman and a poet. As one of the bestselling writers of her time, Felicia Hemans took advantage of her newfound position as a "poetess". Her poetry often playing into mild, domestic feminine ideals while also critiquing such stereotypes in subtle ways (6). 
In a time that was preoccupied with melancholic emotions, the role of happiness and joy is often overlooked - a preference that is at least partially a gendered one. Adam Potkay defines happiness and joy in contrast to one another: "Happiness is a technology of the self, a fashioning and indemnification that elevates inner integrity, constancy and wisdom over external mutability, loss and death. Joy, by contrast, is an expansion and at least partial loss of the self" (Potkay 3). While these definitions show a distinction between the two emotions - one as a mode of selffashioning and the other as a potentiality of the self - they both include a recognition of loss. This loss of selfhood or connection to external forces involves an almost transcendent quality, demonstrating the ways that loss and fulfillment can work together to achieve higher states of being. Despite these transcendent characteristics, male poets of the period often relied on dark and intense emotions, leaving women writers to engage with more mild and joyful sentimental expressions.

If happiness and joy have been widely disregarded within the Romantic poetic tradition, then cheerfulness has been even more so. The Oxford English Dictionary defines cheerfulness as a "cheerful feeling, mood or temperament", an "alacrity" or "willingness" ("Cheerfulness"). Cheerfulness is defined as a visible presentation of happy emotions, rather than being an emotion in itself. The addition of "alacrity" and "willingness" further positions cheerfulness as a compliant state of being, in which one is attuned to others and ready to submit to their pleasures and needs. These concepts of docility and pleasantness correlate with nineteenth century domestic ideals in their emphasis on mild emotional expression and a woman's role in service to others. Referencing Wordsworth, Ian Dennis describes the power of Romantic joy as "the power to be free of desire but to know of, intimately anticipate, the fulfillment of desire" (Dennis 5). The loss that is built into this emotion is what Dennis calls "the melancholy of Romantic joy" 
(5), which demonstrates the merging of two seemingly contradictory emotions through the mastery of one's desires. If cheerfulness is merely the outward expression of happy emotions, then its hollow nature frees it from the complex workings of desire and melancholy that are inseparable from emotions like joy. In this way, cheerfulness can explore these tensions without being tied to them. Another point of comparison is William Blake's Songs of Innocence and Experience which explores the interrelation between purity and corruption from childhood into adulthood, and the consequences of leading a life that strays too far to one side. Blake's version of innocence, which is represented as a state of ignorance and purity, is similar to the compliancy of cheerfulness. The child-like poems in Songs of Innocence often overlap with themes of corruption from Songs of Experience, highlighting the limitations of each state and revealing the dangers of leading a wholly ignorant or knowledgeable existence. Cheerfulness is useful for its ability to access a middle ground between such oppositional forces. It does not seek the selffashioning of happiness or the self-loss of joy but exists unbounded as an expression of both emotions. It is in this very ambiguity that questions of self, knowledge, and desire can be accessed more openly, especially for women.

In Hemans' "Ode to Cheerfulness", cheerfulness is personified as a woman, her beauty and gentle spirit guiding the speaker through the pains and pleasures of life. The opening stanza describes a "[1]ovely nymph" whose beauty, grace and youth are evoked in great detail, emphasizing the physicality of the female figure. In this sense, both the female form and cheerfulness become focalized around their appearance rather than the deeper workings of the mind and heart. The speaker also compares the woman to a flower, noting her "blooming Hebe dancing" (Hemans, "Ode to Cheerfulness", line 4), "lip of roseate dye" (9), and cheek that glows "[b]righter than the blushing rose" (12). By comparing the woman to the transient beauty of a 
flower, the poem aligns her with nature. Although this correlation often works within larger structures of masculine power, it is not necessarily oppressive in this instance - the repetition of "Thine" at the beginning of lines 9 to 11 emphasizing cheerfulness' self-possession. While the speaker views and describes her aesthetic qualities, the body of cheerfulness cannot be appropriated by outside forces because it ultimately belongs to her. Unlike "Ode on Melancholy" in which the male figure is told to use his mistress' eyes and hands to overcome his melancholic state, the speaker in Hemans' ode recognizes cheerfulness' agency, and while it looks upon her body, it never claims to possess it in the same way.

The speaker is also not gendered in the ode but remains ambiguous in its relation to the self and the feminized cheerfulness. Although the melancholic figure in Keats' ode is similarly ungendered, the sexual encounter with the mistress suggests a masculine identity. Hemans presents a relationship that is not bound by heteronormative structures but exists largely outside of the sexual ties that limit women's selfhood. In addition, this ambiguity gives power to the poetic voice, suggesting that the authorial speaker is not inherently male or female, but works beyond the limitations of both genders. The relationship between the speaker and the feminine cheerfulness is also not a dominant or hierarchical one, the speaker declaring: "Ever let me own thy sway,/ Still to thee my tribute pay" (17-18). This statement shows the inherent influence and power of cheerfulness, that she has a "sway" which cannot be owned without her permission. The speaker even concedes that if this permission were granted, they would still pay tribute to her. The authoritative voice of the speaker relinquishes control to cheerfulness and reverses the power dynamics between subject and observer, a relationship that was deeply embedded in the gender politics of the nineteenth century. As demonstrated through the works of Keats, the male poetic gaze served as a mode of controlling and objectifying women, especially given the 
growing female readership that was developing at the time. However, in Hemans' ode the repetition of phrases such as "Guide me" (13), "With thee, sweet maid" (27), and "I court thee" (39) establish a sense of reciprocity and even gesture towards an equality between the two figures. The speaker and cheerfulness work together to shape the poem and the workings of life. This egalitarianism is focalized in Hemans' work and in the work of other women writers of the Romantic period.

Charlotte Smith used her voice to challenge the role her gender played in her career as a poet and novelist, and considering her approach to emotions such as melancholy, helps us to contextualize Hemans's achievement. Although she was one of the most popular writers of the Romantic period, given the social limitations of her gender, Smith could not attain the same canonized success as male poets writing at the same time and about similar themes. Melancholy played a significant role in Smith's poetry, serving to relay the oppressive conditions of life for women and subverting conceptions that a woman must remain good tempered and not display powerful emotions. Smith's “To Melancholy” from Elegiac Sonnets, and Other Poems was published almost forty years before Keats' ode, however, the two present similar explorations of the emotion from vastly different perspectives. Smith's conception of melancholy is much milder than Keats', as she describes its ability to "soothe the pensive visionary mind!" "'To Melancholy", line 14). Melancholy is not something sublime or dangerous, but soothing and ever-present in the poetic mind. The "I" in the poem also aligns Smith's voice with poetic creation, establishing melancholy as a real emotion felt by women and as "the authentic voice, and effect, of social causes and grievances" used by women writers (Wolfson 444). Despite this use of masculine themes and tropes, Smith's "To Melancholy" is not as widely recognized in the canon of Romantic poetry as Keats' ode. 
"Sonnet XII: Written on the Sea Shore. - October, 1784" is another poem from Smith's Elegiac Sonnets that explores women's emotional expression. The use of pathetic fallacy and fragmented imagery shows the underlying power of women's emotions, the solitary female figure set within a liminal space where the land meets the sea. The speaker compares herself to a drowning mariner, who is eventually overcome by the tumultuous waters (Smith, "Written on the Sea Shore", line 10). In this simile, Smith compares the emotional exhaustion of a woman to the physical exertion of a man who is overwhelmed by nature. This alignment not only validates women's emotions but further establishes the female speaker's experience as real, and the man's as imaginary - giving the woman the authorial voice and using the man a constructed point of comparison. In a time that discredited women's emotions as imaginary or hysteric, this gendered reversal between who is allowed to express their emotions and who must suffer silently, authenticates the power and truth behind women's emotional experiences.

Women were both grounded and groundless in the nineteenth century, constrained to an earthly plane that ultimately dismisses them because of their gender. For women writers this issue is made even more complex. Marlon B. Ross describes how Charlotte Smith attempted to disenfranchise male structures of power by borrowing their discourse, only to have her work dismissed into the feminine realm of the domestic based on her inability to escape these structures (Ross 207). The structures of power that hindered Smith's ability to achieve canonization made the path towards poetic transcendence just as easy for her male contemporaries. Katherine M. Rogers asserts that "as a woman writing about women, [Smith] could not claim the boundless power of the Romantic imagination" (Rogers 72). How can a woman transcend a world and its structures of power - both emotionally and artistically - if she is not first allowed to be fully a part of that world? In this sense, poets like Smith and Hemans 
must first transcend the very social structures that work to ground them, facing additional barriers in pursuit of great artistic creation and the promise of an enduring reputation. Although Smith achieved success in her lifetime, until recently she was not as widely read or remembered in the study of Romantic poetry, suggesting an inherent gender bias in the canon of great Romantic art.

Similarly, Hemans attempts to overcome these gendered barriers by unsettling Romantic conventions in her poetry. Cyclical imagery is used in "Ode to Cheerfulness" to demonstrate a feminized connection to nature, however it is not done in an oppressive or patriarchal way. In stanzas 3 to 6 , the speaker moves from Spring to Winter, describing a changing relationship to cheerfulness as they progress through life's many stages. These stanzas take on a longstanding comparative tradition, however, what is significant about this passage is that the lifespan does not end with the "hoary reign" of winter (Hemans 35). In stanza 7, the speaker reintroduces "the vernal hours" (39), emphasizing the continuation of life after death and times of despair. The continuous cycle of nature establishes a sort of immortality, which considered in relation to the gender dynamics already present in the poem, acts as a form of genderless transcendence. When examined from a female perspective, women's connection to nature aligns them more deeply with this immortality, both serving as vessels of life and creation beyond any social limitations. In "The Ruin and Its Flowers," Hemans explores similar themes, the poem describing the tomb of warriors and minstrels whose music and memory are only revived through the presence of a muse. The transience of masculine accomplishment is contrasted by the power of beauty to "grace the ruin in its fall" (Hemans, “The Ruin and Its Flowers", line 95), suggesting women's sustained role in the creation of both art and meaning. In this way, Hemans is subverting the 
tradition of aligning women with nature by using their connection to develop themes of feminine strength and immortality.

Keats" "Ode on Melancholy" emphasizes the transience of female beauty and identity. The focus on death in the final stanza - with the exclamation that Beauty "must die" - grounds women and places them out of reach of transcendence. If women are tied to their appearance, then their worth dies along with their beauty and their ability to serve men. However, in Hemans' poetic conception, a woman's connection to nature places her within an ecological cycle, demonstrating the potential for regeneration and even immortality. While this can act as a limiting perspective, it also establishes the possibility of aligning women and nature as boundless creators. The connection between the creation of life and the creation of art further solidifies the rightful place of women within the canon of great poets.

In addition to the themes working within the poems, the form of the ode itself also plays into larger gender conventions of the time. While the ode was a prevalent form among male poets, the Romantic period saw a rise in odes of sentiment, a mode of expression often used by women writers (Schor 113). In her collection on the domestic affections, Hemans uses the ode to address various subjects, including experience, resignation and fancy. Esther Schor argues that the Romantic ode contains an inherent "entanglement of liberty and power" (107) and that one of the Romantic legacies of the ode is "the trick of demystifying the transcendent and celebrating the mundane" (119). Hemans seems to be exemplifying these odic qualities, her "Ode to Cheerfulness" favouring the mild experiences of the everyday rather than of powerful sublimity. In highlighting mundane experiences and presenting them as divine and worthy of poetic expression, Hemans could be seen to be working within this inherent entanglement of liberty and power to establish a more elevated position for women. 
"Ode to Cheerfulness" aligns itself with other poems in The Domestic Affections which also serve to challenge conventional interpretations of a woman's role in society. In the final poem, "The Domestic Affections", for which the collection is named, Hemans undermines the affections by conjuring images of chaos and violence that work to discredit the idealized domestic realm. She describes a sailor who dies in a shipwreck (Hemans, "The Domestic Affections", lines 101-104) and the violent hauntings of a soldier returning home (149-152) against the serenity of the affections and domestic spaces. This tension between gendered spheres resonates with much of Charlotte Smith's poetry, the dying sailor in "The Domestic Affections" harkening back to Smith's mariner in "Written on the Sea Shore. - October, 1784". As Seth Reno states: "The affections are also more than domestic: they can produce a shared affective state that effectually links individuals - and, by extension, nations - through a politicized sympathy. Hemans draws attention to the political and epistemological implications of emotion rather than casts the affections as a way to escape earthy problems" (Reno 11). Hemans further grounds herself in order to make a larger social critique, using the domestic affections to bring people and ideas together rather than seek a more individualistic transcendence. Even though Hemans constantly returns to the "consoling light" (433) of "mild affections" (433), the exploration of mortality, gender, and war unsettle a passive understanding of the affections and how they define people and political structures. In this way, her writing and its exploration of sentiment follows the example of Blake's Songs of Innocence and Experiencehighlighting the complexities of purity and corruption, and how they work together to create meaning and truth.

In the eighth stanza of "Ode to Cheerfulness", the poem shifts its tone to uncover a more peaceful mode of transcendence that qualifies the ideals of melancholy and sublime experience, 
making them less categorical and exclusive. In the final stage of life, the speaker asks the "gentle pow'r" (Hemans 48) of cheerfulness to guide their way with "mild celestial light" (52). This "mild" and "gentle" power is not depicted as a weakness - as it is in Burke's definition of the sublime - but allows cheerfulness to permeate one's life to provide support and stability. Looking more closely at Burke's conception of the sublime, which asserts the contradictory and all-powerful nature of the experience, Hemans' final quest for "mild celestial light" would seem minor and even feeble in comparison. However, this mild light is also given power to "gild the dark and thorny way" (51), proving its strength over dark emotions and even the painful experience of death. In overcoming such sorrow, cheerfulness becomes an alternative to both the masculine experience of the sublime and melancholy. Even though it is "mild" - and therefore in accordance with feminine ideals - cheerfulness is also described as "celestial", giving it a divine and transcendent quality. In this way, Hemans rejects the sublime and melancholy in favour of more gender-neutral modes of transcendence.

In poems such as Keats" "Ode on Melancholy", darker emotions seem to take precedence, with pain arising from pleasure rather than the other way around. In the maledominated world of the Romantic period, men were able to take pleasure for themselves, but for women this process was not so straightforward. Writers such as Felicia Hemans and Charlotte Smith were forced to work through the inherent melancholy of an oppressive existence before achieving states of pleasure or transcendence. Despite the success she gained from her writing, Smith's literary career started based on necessity. As the wife of a frequent gambler with twelve children to take care of, Smith's poetry served as a means of supporting herself and her family. The title of her famous collection, Elegiac Sonnets, and Other Poems, suggests a sorrowful tone and she expresses in the preface to the sixth edition that "[she] wrote mournfully because [she] 
was unhappy" (Smith, "Preface to the Sixth Edition"). As Wolfson notes: "Women write with a melancholy tinge because they are melancholy, and they are melancholy because in 'society' they are "women'” (Wolfson 445). Women attempt to escape this melancholy, whereas men seek it out, yearning for an experience that is not as deeply embedded in their lives. In this way, melancholy acts as a means of attaining transcendence for male poets - of surmounting the everyday and discovering the extraordinary in the ordinary. For women melancholy is a reality that must be overcome in order to achieve higher states of being - or even merely to survive.

For many women writers, the thought of transcendence would have been a luxury that was largely inaccessible to them, and any thought of their posthumous reputation would come second to financial stability. Similar to Smith's experience, Hemans' career started based on her family’s financial insecurity - her mother publishing Hemans' poetry to pay for her education when she was only fourteen years old (Feldman 149). Even after the publication of The Domestic Affections, Hemans expressed in a letter to her publisher that she "shall have fixed upon a subject likely to excite a more general interest than [her] former publications could claim" (154). The main priority of Hemans' writing was therefore not artistic esteem or canonization, but to please her audience and establish a source of income. Male poets had the freedom and privilege to think about the legacy of their work, whereas women like Smith and Hemans had to first contend with immediate realities, which often limited the full potential of their poetry.

In Hemans' ode, the fact that cheerfulness is present even near the end of a person's life, shows that there can be joy and pleasure in melancholic occurrences. Perhaps Hemans is suggesting that melancholy is not a fixed state of being, but that there is something more sustainable if not more powerful lying beneath the surface. It is not about attaining all-powerful experiences but finding that "mild celestial light" in any situation. From this perspective, 
Hemans rejects a masculine coded version of transcendence in favour of something mild and ungendered, the "gentle pow'r" that endures amidst death and hardship and uplifts all living beings. Wolfson, again, argues that "Hemans' genius was her bending the cultural ideal of 'feminine' into dark contradictions" (Wolfson 445). In this poem, such contradictions cheerfulness and melancholy, transcendence and female identity - work together to establish something cohesive and permanent. Cheerfulness and mild emotion are therefore not idealistic, but subversive and even optimistic, challenging what it means to be a woman in the nineteenth century and to what end this identity can support an artistic existence.

Unlike the title of Keats' ode, which adopts a dominant stance on melancholy, 'Ode to Cheerfulness" addresses the subject it explores more openly. The feminized cheerfulness is addressed from the beginning, the speaker's opening exclamation to the "[l]ovely nymph" serving to direct attention to the subject itself, rather than the speaker's interpretation of it. By addressing the poem "to" its subject, the ode also acknowledges the role of cheerfulness in its creation. While cheerfulness is addressed, it is never actually mentioned in the poem itself. She is merely presented as a female form, evoking a sense of cheer without being named as such. By contrast, Keats' melancholy is mentioned twice, once as an emotional state and later as a personified temptress. By moving from an elusive emotion to a physical being, melancholy is made more finite and controllable. This act of naming within the poem limits the expression of melancholy and establishes her as a possession rather than a sentiment. For Hemans, cheerfulness is never pinned down in the same way, but exists without boundaries, her nature and the skill of the poet evoking the feeling of cheerfulness without the constraints of a name.

The power of melancholy and cheerfulness is ultimately determined based on their proximity to the other figures within the poems. Hemans portrays two figures in her ode, the 
ungendered speaker and the feminized cheerfulness; whereas Keats portrays three major figures, the speaker, the melancholic man, and Melancholy. The addition of this third body - through which the speaker interprets and engages with melancholy - places the female form further from the authorial voice of the speaker. By positioning the speaker and cheerfulness in direct relation to one another, Hemans aligns their experiences, directing women ever closer to the transcendent realm of poetic creation and canonization.

\section{Conclusions}

John Keats" "Ode on Melancholy" aligns melancholy and the sublime as transcendent and inherently masculine - experiences. The feminization of melancholy and the connection between the female form and nature, work to relegate women to an earthly sphere - acting as vehicles for male sublimity rather than agents of their own transcendence. By contrast, Felicia Dorothea Hemans' "Ode to Cheerfulness" establishes a middle ground between the masculine sublime and a feminized connection to nature, by depicting cheerfulness as an ungendered and alternate method towards transcendence. The interrelation between female identity and cheerfulness, and the final attainment of "mild, celestial light", demonstrate a more enduring and accessible method of transcendence that is not limited by one's gender. While the two odes address different emotional states, they both illustrate the interconnectivity between gender, emotion, and space, to establish distinct and opposing representations of sublimity.

Within Romantic literature, sublime experience and melancholy are methods towards transcendence for male poets and grounding for women, limiting the potential of women writers to achieve higher states of being and establish an enduring legacy. Poets such as Felicia Hemans and Charlotte Smith challenge these masculine modes of transcendence, working within 
established gender conventions to create a broader vision of women as not only artists, but emotionally complex people. Despite their differences, "Ode on Melancholy" and "Ode to Cheerfulness" illustrate the interdependence of oppositional forces to enable a fuller experience of life and art. Keats illustrates the underlying pain in all pleasure, whereas Hemans finds peace amidst life's chaos. For both poets, this interplay between dualities is central to their representations of the world and the experience of emotion. Viewing the Romantic period as privileging darker emotions such as melancholy limits the ways it is understood and stifles the intersections between emotion, gender, and authorial power. The gendered implications of Romantic melancholy exclude women from the canon of great art, as they were unable to freely express themselves to the same extent as their male contemporaries. By embracing the interconnectivity between melancholy and cheerfulness, the sublime and the domestic, a more complete and accessible vision of Romanticism can be uncovered and sustained. 
Works Cited

Banerjee, Argha. Female Voices in Keats's Poetry. Atlantic Publishing, 2002.

Bennett, Andrew. Romantic Poets and the Culture of Posterity. Cambridge University Press, 1999. ProQuest Ebook Central, https://ebookcentral-proquestcom.ezproxy.lib.ryerson.ca/lib/ryerson/reader.action?docID=141568.

Bowring, Jacky. A Field Guide to Melancholy. Oldcastle Books, 2008.

Burke, Edmund. "A Philosophical Inquiry into the Origin of our Ideals of the Sublime and Beautiful." The Works of the Right Honourable Edmund Burke, Project Gutenberg, 2004, https://www.gutenberg.org/files/15043/15043-h/15043-h.htm\#CONTENTS.

Burton, Robert. The Anatomy of Melancholy. Project Gutenberg, 2004. Project Gutenberg, http://www.gutenberg.org/files/10800/10800-h/10800-h.htm.

“Cheerfulness.” OED Online, Oxford University Press, 2020, https://www-oedcom.ezproxy.lib.ryerson.ca/view/Entry/31150?redirectedFrom=cheerfulness\&.

Day, Aidan. "Enlightenment and Romantic." Romanticism, $2^{\text {nd }}$ ed., Taylor \& Francis Group, 2012, pp. 113-185. ProQuest Ebook Central, https://ebookcentral-proquest com.ezproxy.lib.ryerson.ca/lib/ryerson/detail.action?docID=838152\#.

Dennis, Ian. "Romantic Joy: A Definition and A Deployment." Anthropoetics: The Journal of Generative Anthropology, vol. 16, no. 1, 2010. Directory of Open Access Journals, http://anthropoetics.ucla.edu/ap1601/1601dennis/.

Dolan, Elizabeth A. "British Romantic melancholia: Charlotte Smith's Elegiac Sonnets, medical discourse and the problem of sensibility." Journal of European Studies, vol. 33, no. 3-4, pp. 237-253, 2003. Gale Literature Resource Centre, https://go-gale- 
com.ezproxy.lib.ryerson.ca/ps/i.do?p=LitRC\&u=rpu_main\&id=GALE\%7CA112483586 $\& \mathrm{v}=2.1 \& \mathrm{it}=\mathrm{r} \& \mathrm{sid}=$ summon.

Feldman, Paula R. "The Poet and the Profits: Felicia Hemans and the Literary Marketplace." Keats-Shelley Journal, vol. 46, 1997, pp. 148-176. JSTOR, https://www-jstororg.ezproxy.lib.ryerson.ca/stable/30210372?pqorigsite=summon\&seq=7\#metadata_info_tab_contents.

Hemans, Felicia. "Ode to Cheerfulness." The Domestic Affections and Other Poems, edited by Nancy Kushigian, University of California, 1998, https://quod.lib.umich.edu/b/bwrp/HemaFDomes?view=toc.

Hemans, Felicia. "Song. The Smile." The Domestic Affections and Other Poems, edited by Nancy Kushigian, University of California, 1998, https://quod.lib.umich.edu/b/bwrp/HemaFDomes?view=toc.

Hemans, Felicia. "To my Mother." The Domestic Affections and Other Poems, edited by Nancy Kushigian, University of California, 1998, https://quod.lib.umich.edu/b/bwrp/HemaFDomes?view=toc.

Hemans, Felicia. “The Ruin and its Flowers.' The Domestic Affections and Other Poems, edited by Nancy Kushigian, University of California, 1998, https://quod.lib.umich.edu/b/bwrp/HemaFDomes?view=toc.

Hemans, Felicia. "The Bards, To the Soldiers of Caractacus." The Domestic Affections and Other Poems, edited by Nancy Kushigian, University of California, 1998, https://quod.lib.umich.edu/b/bwrp/HemaFDomes?view=toc.

Homans, Margaret. “Keats Reading Women, Women Reading Keats.” Studies in Romanticism, vol. 29, no. 3, 1990, pp. 341-370. JSTOR, https://www.jstor.org/stable/25600850. 
Keats, John. "Ode on a Grecian Urn." Representative Poetry Online, University of Toronto, https://rpo.library.utoronto.ca/poems/ode-grecian-urn.

Keats, John. "Ode on Melancholy.” Representative Poetry Online, University of Toronto, https://rpo.library.utoronto.ca/poems/ode-melancholy.

Krsmanovic, Ivana M. "To George and Georgiana Keats 14-31 October 1818.” The Keats Letters Project, https://keatslettersproject.com/category/correspondence/to-george-andgeorgiana-keats-14-31-oct-1818/.

“Letter \#99: To Richard Woodhouse, 27 October 1818.” The Keats Letters Project, http://keatslettersproject.com/letters/letter-99-to-richard-woodhouse-27-october-1818/.

"Melancholy." Encyclopedia of Aesthetics, edited by Michael Kelly, $2^{\text {nd }}$ ed., Oxford University Press, 2014. Oxford Reference, https://www-oxfordreferencecom.ezproxy.lib.ryerson.ca/view/10.1093/acref/9780199747108.001.0001/acref9780199747108-e-494?rskey=8taJE2\&result=2.

Mellor. Anne K. Romanticism and Gender. Routledge, Taylor and Francis, 1993.

Potkay, Adam. The Story of Joy: From the Bible to Late Romanticism. Cambridge University Press, 2011.

Reno, Seth. "Felicia Hemans and the Affections." CEA Critic, vol. 77, no. 1, 2015, pp. 4-24. Research Library, file:///Users/owner/Downloads/Felicia_Hemans_and_the_Affecti.pdf. Rogers, Katherine M. "Romantic Aspirations, Restricted Possibilities: The Novels of Charlotte Smith.” Re-visioning Romanticism: British Women Writers, 1776-1837, edited by Joel Haefner and Carol Shiner Wilson, University of Pennsylvania Press, 1994, pp. 72-90. EBSCOhost, https://web-a-ebscohostcom.ezproxy.lib.ryerson.ca/ehost/ebookviewer/ebook/bmxlYmtfXzE3NDk3X19BTg2?si 
d=170b52b2-e396-4a52-a5a7-a593ac5ac578@sdc-v-

sessmgr02\&vid=0\&format=EB\&lpid=lp_III \&rid=0.

Ross, Marlon B. “Configurations of Feminine Reform: The Woman Writer and the Tradition of Dissent.” Re-visioning Romanticism: British Women Writers, 1776-1837, edited by Joel Haefner and Carol Shiner Wilson, University of Pennsylvania Press, 1994, pp. 91-110. EBSCOhost, https://web-a-ebscohostcom.ezproxy.lib.ryerson.ca/ehost/ebookviewer/ebook/bmxlYmtfXzE3NDk3X19BTg2?si d=170b52b2-e396-4a52-a5a7-a593ac5ac578@sdc-vsessmgr02\&vid=0\&format=EB\&lpid=lp_III \&rid=0.

Schor, Esther. "'Stirring Shades': The Romantic Ode and its Afterlives." A Companion to Romantic Poetry, edited by Charles Mahoney, Blackwell Publishing, 2011, pp. 107-122. Smith, Charlotte. "Preface to the Sixth Edition." Elegiac Sonnets, and Other Poems, edited by Nancy Kushigian, University of California, 2000, https://quod.lib.umich.edu/b/bwrp/SmitCElegi/1:8?rgn=div1; view=fulltext.

Smith, Charlotte. "Sonnet XXXII: To Melancholy. Written on the Banks of the Arun, October, 1785.” Elegiac Sonnets, and Other Poems, Text Creation Partnership, 2011, https://quod.lib.umich.edu/e/evans/N22357.0001.001/1:10?rgn=div1;view=fulltext.

Smith, Charlotte. "Sonnet XII: Written on the Sea Shore. - October, 1784." Elegiac Sonnets, and Other Poems, Text Creation Partnership, 2011, https://quod.lib.umich.edu/e/evans/N22357.0001.001/1:10?rgn=div1;view=fulltext.

Wolfson, Susan J. "Romanticism \& Gender \& Melancholy." Studies in Romanticism, vol. 53, no. 3, pp. 435-456. JSTOR, https://www.jstor.org/stable/24247282. 